\title{
THE PERSONALITY OF AMIR TIMUR AND HIS EPOCH DESCRIPTION IN STORY LORD OF SAMARCAND BY ROBERT E. HOWARD
}

\author{
CYakubov M., ORCID: 0000-0001-6009-0384, Urgench State University, \\ Urgench,Uzbekistan, muzaffarbek.yakubov0055@gmail.com
}

\section{ОБРАЗ АМИРА ТИМУРА И ОПИСАНИЕ ЕГО ЭПОХИ В ПРОИЗВЕДЕНИИ РОБЕРТА ГОВАРДА «ПОВЕЛИТЕЛЬ САМАРКАНДА»}

\author{
(СЯкубов М. К., ORCID: 0000-0001-6009-0384, Ургенчский государственный университет, \\ г. Ургенч, Узбекистан, тиzaffarbek.yakubov0055@gmail.com
}

Abstract. This article deals with the image of Timur the Great and description of his epoch in the story Lord of Samarcand by well-known American writer Robert E. Howard.

Аннотация. В статье идет речь об образе Амира Тимура и описании его эпохи правления в произведении Роберта Говарда «Повелитель Самарканда».

Keywords: Lord of Samarcand, personality, epoch, history, Picts, hero, authentic, source.

Ключевые слова: Повелитель Самарканда, образ, эпоха, история, пикты, герой, достоверный, источник.

Working on my scientific research named "The personality of Amir Timur in Englishspeaking literature", I run into the information, which, if to say honestly surprised me most. It turns out that, not only Christopher Marlowe, Nicholas Rowe, Edgar Poe (these authors mostly known among others) had their compositions about Timur the Great, but also Robert Howard. I want to write, with great pleasure and honour, giving sincere respect, about this great writer - Robert Howard (full name is Robert Irvin Howard / Robert Ervin Howard) is an American writer who worked in the genre of fiction. He is mostly known for his character Conan the Barbarian films starring Arnold Schwarzenegger and regarded as the founder of the sword and sorcery subgenre. He was born in Pester, Texas, and lived a very short life (1906-1936).

His father is Isaac Mordecai Howard, a rural doctor and his mother suffering from pulmonary tuberculosis is Hester Jane Irvin. Howard was an only child in the family. He spent his childhood and adolescence touring various cities and villages. Howard's mother, who was dissatisfied with her husband's relationship with her son, had a profound effect on Robert [1], she would recite him poems awaking her son interest and love for literature and poetry and she was eager to support, with great pleasure, Robert's interest in literature [2]. When Robert saw his mother suffering from a vengeful and incurable illness, he regarded the environment as cruel. The sudden death of Robert, a powerful talent, was also due to his mother's illness (Robert suicided after his mother's falling into coma).

His love to books, his innate talent and the support of his mentors inspired him to have desire to become a professional writer. At the age of nine, he began writing short stories, most of them were historical fiction about Vikings and Arabs, and, in general, stories full of the war spirits. The writers who had salutary influence on Robert were Jack London, Rudyard Kipling, Thomas 
Bulfinch. His friends said that Robert had a strong memory and he could remember the great poems after reading them once or twice [3].

At age of 13, his family moved to Cross Plains, a city in central Texas. Here, Howard encountered a book that contains a variety of tales and legends about barbaric tribes, which had played a major turning point in his life. This book describes the ability of the free and powerful people of ancient Scotland to live their lives in hard working and fighting. From that point on, Picts acted as the author's inspirational muse in his creative works.

At the age of fifteen, Howard participated in small (pulp) magazines, most notably Adventure magazine, at that time, when great writers such as Talbot Mundy and Harold Lamb made their own compositions and were published [4]. In the following years, he created a variety of characters, and his stories were issued in the famous publishing houses. No one taught him or guided him, he wrote stories on paper with his innate talent.

In 1922, Howard moved to Brownwood to finish high school. Here he met like-minded and unanimous people - Tevis Clyde Smith and Truett Winson. Together they published newspapers and magazines and wrote long letters to each other, filled with thoughts about poetry and life. The first stories "Golden Hope 'Christmas" and "West is West" which won the gold and silver awards were published in Thewood's local newspaper The Tattler, thanks to Vinson efforts [5].

At the age of 23, Robert Howard became famous and greatly improved his financial position. In the 1930th he began the "Celtic era" in his work, during which he became interested in the history of the Celts and his own Irish roots. He shares his impressions with his friend Harold Preece. In his letters, Howard gave information and comments on the Irish theme. He learned the language for some time and created the characters of Irish heroes - Turlogh Dubh O'Brien and Cormac Mac Art.

Later he returned to his favourite theme - Picts. "King of the Night" - is the story, in which Howard sends King Kull to pre-Christian Britain Picts to help with the fight against the Romans, and introduces the reader to King of the Picts Bran Mak Morn.

At this period to Howard's happiness began to appear a new magazine called "Oriental Stories" (later called "Magic Carpet"), which gave him a chance to publish his previously unreleased favorite works of historical periods and wars. It was in this magazine that Howard had created such works that he was able to compete with his other stories and examples of his best work Conan (Conan. 1932). These works are devoted to depicting various events and places, from the time of the Roman Empire to the XVth century. Howard loved history, and that is why he often referred to historical stories. However this process demanded from Howard to work hard to create a work on historical subject, because Howard did not like to be based on ambiguity and lies.

Thus, among the several works in the Oriental Stories, there is a nine-part work entitled "Lord of Samarcand" (Oriental Stories, Spring 1932) (not having printed - original version of this work, we had to give later examples from this e-source - http:// en.wikisource.org/wiki/Author:Robert_Ervin_Howard) called the Lord of Samarcand. The work beautifully illustrates the epoch of Amir Temur, its modernity, the beautiful setting of towns and villages in the territories occupied by the Sahibkiran, especially beautifully described in the author's pen the capital city, Samarcand. The details of the fight against the Turkish Sultan Bayazid (there are different views in the world literature about the relationship between Amir Temur and Yildirim Beyazit. Also Robert Howard in his given work describes the relationship of Amir Temur and Boyazid, about which we are going to speak in detail in our next publication) and the plans for China were also described.

The story begins with a battle scene between the Turkish Sultan and the knights of Austria, Germany and Italy. Amir Temur sends his commander Ak Boga to the scene to find out the outcome 
of the fight. The battle ends with the defeat of the European knights, and the commander quickly travels to Samarkand to report the news to the Amir, and on his way he encounters a Scottish knight, who was dissatisfied with the outcome of the fight and wanted to take revenge on Bayazid. Knight agrees to go with Ak Boga to meet Amir Temur in order to fulfill his purpose.

The first words about Timur Robert expresses by the words of the commander of Amir Temur, Ak Boga, says to the Scottish knight :

"Timour, the Servant of God, by the favor of Allah, Amir of Tatary."

The heroes (Ak Boga and the knight of Scotland) took their way to Samarcand, during a trip they stopped at a special checkpoint on a sidewalk, while tall soldiers in iron armor gave them fresh food and exchanged horses for them:

"... and when the Tatar began to stop at wayside posts where tall dark men in iron helmets brought fresh steeds. ... and he wondered at the distance they had covered between the first post where saddled steeds awaited them ..."

Historical sources also confirm that Amir Temur erected such places in his kingdom. The book Amir Temur in World History states:

"There are also stops for horses. Such places were on all the important caravan routes that could replace horses that were always tired "[6]. (the following authentic information are taken from fundamental research source made by group of well known Uzbek and foreign scientists, published in Uzbekistan in 2001)

This shows that Robert Howard was aware of the rules established in the kingdom of the Sahibkiran.

Every architectural monument, built in Samarkand during the period of ruling Amir Temur, had a unique, complete and perfect appearance, from the foundations to the ends of the dome, from tiles to bricks. And Howard describes Samarcand in the Scottish knight's eyes as follows:

"The city shimmered to his gaze, mingling with the blue of the distance, so that it seemed part of the horizon, a city of illusion and enchantment. Blue: the Tatars lived in a wide magnificent land, lavish with color schemes, and the prevailing motif was blue. In the spires and domes of Samarcand were mirrored the hues of the skies, the far mountains and the dreaming lakes." It means that Howard deeply researched the historical materials to give detailed and correct information to the reader, we mentioned above about his responsibility and attitude to writing historical works.

"The city was shining and the blue colours, as if it were a part of the horizon, gave it a charm, a place of magic and charm. The Tatars lived in a vast area where the buildings were built of different colors, but their favorite color was blue. The buildings of Samarkand were a reflection of the horizon, long mountains and quiet lakes.

Ak Boga also tells how Samarcand was built during the reign of Amir Temur:

"You have seen lands and seas no Frank has beheld," said Ak Boga, "and rivers and towns and caravan trails. Now you shall gaze upon the glory of Samarcand, which the lord Timour found a town of dried brick and has made a metropolis of blue stone and ivory and marble and silver filigree."

We know that Amir Temur paid a special attention to the trade and created all the necessary comfortable conditions for the merchants. Some scholars [7] who have studied the trade relations in the period of Amir Temur and the Timurids have said that Amir Temur and the Temurids controlled the main Silk Road - trade route and thus the safety of caravans between China, India, Central Asia and the Middle East with other cities of Europe, in this way they greatly contributed to the development of trade and diplomatic relations between the East and the West [8].

The following lines show that Robert Howard was also well aware of Amir Timur's benevolent policy: 
"... camel-caravans and mule-trains whose robed drivers shouted incessantly, all bound for the Turquoise Gates, laden with spices, silks, jewels, ... the goods and gauds of India and Cathay, of Persia and Arabia and Egypt."

The author acknowledged that all caravans filled with various spices, silks, and precious stones were heading towards the Turquoise Gates, not only India and China, but also Persian, Arabian and Egyptian products are presented here, in Samarcand. And in the words of commander of Great Timur the author rightly says:

"All the East rides the road to Samarcand"

Howard goes on to state his thoughts on the palace of Samarkand, the broad streets of the city, noisy bazaar with representatives of different countries and peoples:

"They rode through the wide winding streets, past palace and market and mosque, and bazaars thronged with the people of a hundred tribes and races, bartering, disputing, shouting. The Scotsman saw hawk-faced Arabs, lean apprehensive Syrians, fat fawning Jews, turbaned Indians, languid Persians, ragged swaggering but suspicious Afghans, and more unfamiliar forms; figures from the mysterious reaches of the north, and the far east; stocky Mongols with broad inscrutable faces and the rolling gait of an existence spent in the saddle; slant-eyed Cathayans in robes of watered silk; tall quarrelsome Vigurs; round-faced Kipchaks; narrow-eyed Kirghiz; a score of races whose existence the West did not guess. All the Orient flowed in a broad river through the gates of Samarcand."

The Scottish knight, Donald MacDeesa, is delighted by the sight, and says in his heart:

"... the cities of the West were hovels compared to this."

Ak Boga and the Scottish knight pass through the library, the academy, and the specially designed recreation area, and the broad lobby guarded by the silver lions:

"Past academies, libraries and pleasure-pavilions they rode, and Ak Boga turned into a wide gateway, guarded by silver lions."

As the story progresses, the Scottish knight, accompanied by the commander

of the Sahibkiran, is brought to the palace and sees among the pillars erected in the palace a rose garden, cherry trees and strange plants, a fountain of silver water:

"The Scotsman, looking between the slender trunks, saw shimmering expanses of roses, cherry trees and waving exotic blossoms unknown to him, where fountains jetted arches of silver spray."

Amir Timur and the Scottish knight come to the palace glittering in blue and gold in the sunshine, pass through high marble columns and enter the hotel through the gilded arches:

"So they came to the palace, gleaming blue and gold in the sunlight, passed between tall marble columns and entered the chambers with their gilt-worked arched doorways, and walls decorated with delicate paintings of Persian and Cathayan artists, and the gold tissue and silver work of Indian artistry."

The Scottish knight meets Amir Timur and describes him as follows:

"... this, then, was the mysterious Tamerlane, who was already becoming a mythical figure in Western lore. He saw a man as tall as himself, gaunt but heavy-boned, with a wide sweep of shoulders and the Tatar's characteristic depth of chest. His face was not as dark as Ak Boga's, nor did his black magnetic eyes slant; and he did not sit cross-legged as a Mongol sits. There was power in every line of his figure, in his clean-cut features, in the crisp black hair and beard, untouched with gray despite his sixty-one years. ... He was closer to the basic Turanian rootstock ..."

Later, the same knight (Donald MacDeesa) says that he participated in several battles with Amir Temur and appreciated the courage of Sahibkiran:

"When rivers run uphill, Timour will flee ..." 
At the end of the story, the author praises Amir Temur's characteristic policy of "measuring seven times and only then cutting " before any action, and described him as folow:

"When other men looked days ahead, Timour looked years;"

Not having wealth and power, he as a young leader fights against the Mughal invaders and suppresses them. ... He based the great, yet unknown to the world empire, the empire from Gobi (the desert situated in the territory of Mongolia and China) to the Mediterranean sea and from Moscow to Delhi. He opened the gates of the South and the East, and ensured that the wealth of the world came to Samarcand. Having conquered the Turkish Sultan, he saved Europe from the Asian invasion. ...

"As a young chief without wealth or power, he had overthrown his Mongol masters, and mastered them in his turn. ... molded into his growing empire, which stretched from the Gobi to the Mediterranean, from Moscow to Delhi--the mightiest empire the world ever knew. He had opened the doors of the South and East, and through them flowed the wealth of the earth. He had saved Europe from an Asiatic invasion, when he checked the tide of Turkish conquest ..."

One of the major representative of American literature Robert Howard provides ample evidence of Amir Temur's efforts to establish a great empire, his high military intelligence and his creative talents in his "Lord of Samarcand", letting us know and easily understand that he was very much aware of such kind of abilities of Great Timur.

\section{References:}

1. Tompkins, W. A. (2019). Santa Barbara's Royal Rancho: The Fabulous History of Los Dos Pueblos. Pickle Partners Publishing.

2. Clute, J. (1999). Edifice, w: The Encyclopedia of Fantasy, red. John Clute, John Grant, New York: St. Martin's Griffin, 309-10.

3. Finn M. Blood \& Thunder. Monkeybrain, Inc., 2006. - P.41.

4. Eng, S. (1984). Barbarian Bard: The Poetry of Robert E. Howard. The Dark Barbarian. The Writings of Robert E. Howard. A Critical Anthology, 23-64.

5. Louinet, P. (2003). Hyborian Genesis: Part 1. Robert E. Howard, The Coming of Conan the Cimmerian, 429-452.

6. Glenn, L. (1976). The Last Celt. Berkley Windhover Books. 72.

7. Urinboev, A., \& Buriev, O. (1999). Ghinese travel of Giyasiddin Nakkosh.; Rtveladze E. V. The Great Silk road. Encyclopedic Reference. Antiquity and the early Middle Ages. Tashkent: Uzbek national encyclopedia, 280.

8. Ahmedov, B., Mukminova, R., \& Pugachenkova, G. (2005). Amir Timur. 126-141.

\section{Список литературы:}

1. Tompkins W. A. Santa Barbara's Royal Rancho: The Fabulous History of Los Dos Pueblos. Pickle Partners Publishing, 2019.

2. Clute J. Edifice, w: The Encyclopedia of Fantasy, red // John Clute, John Grant, New York: St. Martin's Griffin. 1999. P. 309-310.

3. Finn M. Blood \& Thunder. Monkeybrain, Inc., 2006. P. 41.

4. Eng S. Barbarian Bard: The Poetry of Robert E. Howard // The Dark Barbarian. The Writings of Robert E. Howard. A Critical Anthology. 1984. P. 23-64.

5. Louinet P. Hyborian Genesis: Part $1 / /$ Robert E. Howard, The Coming of Conan the Cimmerian. 2003. P. 429-452.

6. Glenn L. The Last Celt. Berkley Windhover Books. 1976. P. 72. 
7. Urinboev A., Buriev O. Ghinese travel of Giyasiddin Nakkosh.; Rtveladze E.V. The Great Silk road. Encyclopedic Reference. Antiquity and the early Middle Ages. Tashkent: Uzbek national encyclopedia, 1999. P. 280.

8. Ahmedov B., Mukminova R., Pugachenkova G. Amir Timur. 2005. P. 126-141.

Работа поступила

в редакиию 14.11.2019 2.
Принята к публикациии 19.11.2019 2.

Ссылка для циитирования:

Yakubov M. Personality of Amir Timur and His Epoch Description in Story Lord of Samarcand by Robert E. Howard // Бюллетень науки и практики. 2019. Т. 5. №12. С. 536-541. https://doi.org/10.33619/2414-2948/49/66

Cite as (APA):

Yakubov, M. (2019). Personality of Amir Timur and His Epoch Description in Story Lord of Samarcand by Robert E. Howard. Bulletin of Science and Practice, 5(12), 536-541. https://doi.org/10.33619/2414-2948/49/66 